\title{
In- vitro regeneration of an important medicinal plant Centella asiatica $\mathbf{L}$. Urban
}

\author{
Jaheduzzaman*, ${ }^{a}$ M. A. Habib ${ }^{b}$, S. Akter, ${ }^{\text {b }}$ N. A. Banu ${ }^{a}$, R. B. Rahman ${ }^{a}$, \\ T. A. Banu ${ }^{\mathrm{b}}$, S. Khan ${ }^{\mathrm{b}}$ and S. Islam ${ }^{\mathrm{b}}$ \\ ${ }^{a}$ Islamic University of Kushtia and ${ }^{b}$ Biological Research Division, Bangladesh Council of Scientific and \\ Industrial Research,Dhanmondi, Dhaka-1205
}

\begin{abstract}
An in vitro multiple shoot regeneration protocol has been developed for Centella asiatica L. Urban from the nodal and shoot tips explants using MS medium with different concentrations and combinations of growth regulators. Multiple shoot regeneration was observed from both the explants on MS containing either BAP alone or in combination with IAA, NAA and Kn. Of the two explants, nodal segment showed comparatively better response towards multiple shoot regeneration. Maximum multiple shoots were found on MS supplemented with 1.0 $\mathrm{mg} / \mathrm{L} \mathrm{BAP}$ and $0.4 \mathrm{mg} / \mathrm{L}$ NAA. For root induction, well-developed shoots were excised and cultured on both MS and half strength of MS with various concentrations of IBA, IAA and NAA. Profuse healthy rooting was obtained on MS medium containing $0.2 \mathrm{mg} / \mathrm{L}$ IBA. The well rooted plantlets were successfully transplanted to the garden soil and their survival rate under natural condition was $90-95 \%$.
\end{abstract}

Key words: Centella asiatica, Regeneration, Medicinal plant, Node, Shoot tips, Multiple shoot.

\section{Introduction}

Centella asiatica L. Urban belongs to the family Apiaceae (Umbelliferae), commonly known as "Indian pennywort". In Bengali, it is known as Thankuni, Thulkuri, Brahmabuti, Brahmokuti. The plant is a prostrate perennial herb with long stolons up to $2.5 \mathrm{~m}$ long, rooting at the nodes young parts more or less puberulous. It possess $2 \mathrm{n}=18$ chromosomes. Centella asiatica has a pantropical distribution including south-east Asia and extending to some subtropical regions. In Bangladesh, it grows naturally across the country. Sometimes it is cultivated in selected areas for medicinal purpose and as vegetable. It is commonly used to treat dysentery and some people have it as salad (Rahman 2008). The plant enjoys considerable reputation in Indian system of medicine as diuretic, alterative and tonic (Kirtikar and Basu 1975). Centella asiatica contains a variety of biologically active chemical constituents like asiaticoside, madecassoside, centelloside, kaempferol, betulinic and centellic acids (Prajapati et. al. 2006). The whole plant possesses antibacterial, anti-inflammatory, anti-febrile and galactogogic activities. It is used in the therapy of fever, measles, haematemesis, epistaxis, diarrhoea, dysentery and jaundice (Hanida \& Kapoor 1988). Medicinal plants are of great interest to the researchers in the field of biotechnology as most of the drugindustries depend, in part, on plants for the production of pharmaceutical compounds (Chand et. al. 1997). Of the world's 25 best selling pharmaceutical medicines, 12 are plant derived (O'Neill and Lewis 1993).

In recent years, there has been an increased interest in in vitro culture techniques which offer a viable tool for mass multiplication and germplasm conservation of rare, endangered and threatened medicinal plants (Ajithkumar and Seeni 1998, Prakash et. al. 1999). Considering its medicinal properties and over exploitation from natural population the requirement for application of tissue culture techniques in the rapid multiplication of elite clones and germplasm conservation is a crucial prerequisite. Moreover, a stable supply of the bioactive secondary products has become an utmost priority.

There have been a few reports to date on micropropagation of Centella asiatica using shoot tips and nodal explants. However, in Bangladesh, there is no report on the establishment of a micropropagation protocol for Centella asiatica (Rahman 2008). The present study was carried out to establish a simple, reliable and reproducible protocol for largescale plantlets production through tissue culture using shoot tips and nodal segments to meet the requirement of the pharmaceutical industries. 


\section{Materials and Methods}

Nodal and shoot tip segments from healthy plants of Centella asicatica L. Urban were used in the present study. The experiment was conducted at Plant Tissue Culture Section, Bangladesh Council of Scientific and Industrial Research (BCSIR), Dhanmondi, Dhaka. The healthy explants were collected, washed thoroughly under running tap water. Then washed with soft detergent for three times followed by washing with liquid antiseptic (Savlon) and again washed under running tap water for 30 minutes. The explants were then taken in laminar airflow cabinet and washed with $70 \%$ ethanol followed by rinsing with sterile distilled water for three times. Then $0.1 \% \mathrm{HgCl}_{2}$ was added to the flask containing the explants and kept for 6 minutes with constant shaking. Eventuvally the explants were rinsed with sterile distilled water for three-five times to get it remove from $\mathrm{HgCl}_{2}$. The surface sterilized shoots were excised to obtain node and shoot tip explants. Then they were inoculated aseptically onto MS medium containing different concentration and combination of growth regulators.

After regeneration and sufficient elongation, the microshoots were carefully excised and rooted on MS with IBA, IAA and NAA separately. Both proliferation and rooting media contained 3\% sucrose and gelled with $0.8 \%$ agar. The $\mathrm{pH}$ was adjusted to 5.8. All the cultures were maintained in a growth room with a $16 \mathrm{~h}$ photoperiod and temperature was maintained at $25 \pm 2{ }^{\circ} \mathrm{C}$, with $50-80 \%$ relative humidity. Weekly visual observation of culture was made and percentage ofculture showing shoot and root formation was recorded. Data were presented in the tables.

\section{Results and Discussion}

Surface sterilized explants were cultured on MS medium supplemented with different concentrations and combinations of BAP, NAA, IAA, and Kn to observe their effect on multiple shoot development from the shoot tip and nodal segment. Among the all media formulations, BAP and NAA showed the best response towards multiple shoot development. An average of 18 shoots/explants were obtained when nodal segment was cultured on MS medium containing 1.0 $\mathrm{mg} / \mathrm{L}$ BAP and $0.2 \mathrm{mg} / \mathrm{L} \mathrm{NAA}$. On the other hand, an averages of 16 shoots/explants were obtained when shoot tip used as explant on the same medium compositions. Similar results were observed by Hossain et. al. (2000) and Nath and Buragohan (2003) in Centella asiatica. Hossain et. al. (2000) observed best response towards multiple shoot development from stem node as explant on MS medium supplemented with $1.0 \mathrm{mg} / \mathrm{L}$ BAP and $0.5 \mathrm{mg} / \mathrm{L}$ NAA. Nath and Buragohan (2003) observed best multiple shoot development on MS medium supplemented with $4.0 \mathrm{mg} / \mathrm{L} \mathrm{BAP}$ and $0.1 \mathrm{mg} / \mathrm{L}$ NAA. Banerjee et. al. (1999) also reported a protocol for in vitro multiplication of Centella asiatica from leaf explants on MS medium containing $3.0 \mathrm{mg} / \mathrm{L}$ BAP and 0.05 $\mathrm{mg} / \mathrm{L}$ NAA. It has been observed that MS medium supplemented with BAP and NAA at higher concentration promoted callus formation. Similar result was observed by Nath and Buragohan (2003) and Banerjee et. al. (1999).

In another set of experiment, different concentrations and combinations of BAP and IAA were tested to see their effect on multiple shoot regeneration. Among the different concen-

Table I: Effect of different concentrations and combinations of BAP, Kn, IAA, NAA in MS on shoot formation from different explants of Centella asiatica L. Urban

\begin{tabular}{|c|c|c|c|c|c|c|}
\hline \multirow{2}{*}{$\begin{array}{l}\text { Growth } \\
\text { Regulator }\end{array}$} & \multirow{2}{*}{ Concentration } & \multicolumn{2}{|c|}{ Concentration } & \multirow{2}{*}{$\begin{array}{l}\text { Percentage of } \\
\text { Shoot formation }\end{array}$} & \multirow{2}{*}{$\begin{array}{l}\text { Days to shoot } \\
\text { initiation }\end{array}$} & \multirow{2}{*}{$\begin{array}{c}\text { No. of } \\
\text { shoots/explant }\end{array}$} \\
\hline & & Shoot tip & Nodal Segment & & & \\
\hline \multirow[t]{2}{*}{$\overline{\text { BAP }}$} & 1.0 & + & - & 53 & 8 & 09 \\
\hline & & - & + & 58 & 6 & 10 \\
\hline \multirow[t]{2}{*}{$\mathrm{Kn}$} & 1.5 & + & - & 33 & 8 & 08 \\
\hline & & - & + & 33 & 7 & 09 \\
\hline \multirow[t]{2}{*}{$\mathrm{BAP}+\mathrm{NAA}$} & $1.0+0.2$ & + & - & 83 & 8 & 16 \\
\hline & & - & + & 90 & 6 & 18 \\
\hline \multirow[t]{2}{*}{$\mathrm{BAP}+\mathrm{IAA}$} & $1.5+.05$ & + & - & 50 & 8 & 12 \\
\hline & & - & + & 50 & 7 & 13 \\
\hline \multirow[t]{2}{*}{$\mathrm{Kn}+\mathrm{NAA}$} & $1.0+0.6$ & + & - & 30 & 9 & 06 \\
\hline & & - & + & 44 & 7 & 07 \\
\hline
\end{tabular}


Table II: Effect of different concentrations of IAA, IBA and NAA in MS and 1/2 MS on root induction from generated shoots of Centella asiatica L. Urban

\begin{tabular}{|c|c|c|c|c|c|}
\hline \multirow{2}{*}{$\begin{array}{l}\text { Growth } \\
\text { Regulator }\end{array}$} & \multirow{2}{*}{$\begin{array}{l}\text { Concentration } \\
(\mathrm{mg} / \mathrm{L})\end{array}$} & \multicolumn{2}{|c|}{ Media } & \multirow{2}{*}{ Days to root induction } & \multirow{2}{*}{$\begin{array}{l}\text { Percentage of root } \\
\text { induction }\end{array}$} \\
\hline & & MS & $1 / 2 \mathrm{MS}$ & & \\
\hline \multirow[t]{2}{*}{$\overline{\mathrm{IAA}}$} & 0.2 & + & - & 20 & 10 \\
\hline & 0.2 & - & + & 17 & 40 \\
\hline \multirow[t]{2}{*}{ IBA } & 0.5 & + & - & 20 & 20 \\
\hline & 0.2 & - & + & 16 & 60 \\
\hline \multirow[t]{2}{*}{ NAA } & 0.5 & + & - & 22 & 20 \\
\hline & 0.3 & - & + & 19 & 30 \\
\hline
\end{tabular}

trations of BAP and IAA used, best multiple shoot regeneration was observed on MS medium containing $1.5 \mathrm{mg} / \mathrm{L}$ BAP and $0.25 \mathrm{mg} / \mathrm{L}$ IAA. Almost similar results in Centella asiatica were noted by Nath et. al. (2000). Nath and Buragohan (2003) used $1.5 \mathrm{mg} / \mathrm{L} \mathrm{BAP}$ and $0.5 \mathrm{mg} / \mathrm{L}$ IAA for multiple shoot development from nodal explant of Centella asiatica. Rozita et. al. (2004) reported that BAP and IAA are important factors in promoting cell growth of Centella asiatica cell culture.

Effect of different combinations of cytokinin, BAP and Kn were used for multiple shoot regeneration. In this case about 13 shoots/explant were observed when MS medium supplemented with $1.0 \mathrm{mg} / \mathrm{L} \mathrm{BAP}$ and $0.05 \mathrm{mg} / \mathrm{L} \mathrm{Kn}$ (Table I). Hossain et. al. (2005), observed similar response towards multiple shoot regeneration on MS medium containing 1.5 $\mathrm{mg} / \mathrm{L} \mathrm{BAP}$ and $0.2 \mathrm{mg} / \mathrm{L} \mathrm{Kn}$.

From the overall study, it has been observed that nodal explants of Centella asiatica showed better response over shoot tip explant towards multiple shoot development possibly because of their more herbaceous nature.

Different auxins including NAA, IAA and IBA were used in various concentrations in full and half strength of MS basal medium for root induction. Of the three auxins, IBA showed best response on root induction when half MS medium was supplemented with $0.2 \mathrm{mg} / \mathrm{L}$ IBA (Table II). In the present study it was observed that half strength of MS medium was better than full strength of MS medium for root induction. Similar results were also reported by Hossain et. al. (2000), Sivakumar et. al. (2006) in, Nath and Buragohan (2003) in and Nath et. al. (2000) in Centella asiatica.

Plantlets with 3-6 expanded leaves and well-developed roots were successfully transferred to plastic pot containing garden soil and compost in ratio of $2: 1$. The pots were covered with polythene bag to prevent desiccation. About $90 \%$ plants were successfully transplanted to soil.

Results of the present investigation indicated that, it is possible to multiply Centella asiatica in a large scale by culturing shoot tip and nodal explants on MS medium containing $1.0 \mathrm{mg} / \mathrm{L}$ BAP and $0.2 \mathrm{mg} / \mathrm{L}$ NAA. The result may be of great help for the pharmaceutical industries of Bangladesh for large scale in vitro multiplication of Centella asiatica.

\section{References}

Ajithkumar D and Seeni S (1998). Rapid clonal multiplication through in vitro axillary shoot Proliferation of Aegle marmelos (L.) Corr., A Medicinal Tree. Plant Cell Rep. 17: 422-426.

Banerjee S, Zehra M and Kumar S (1999). In vitro multiplication of Centella asiatica, a medicinal herb from leaf explants. Current Science. 76: 110-112.

Chand S, Sahrawat AK and Prakash, DVSSR. (1997). In vitro culture of Pimpinella anisum L. (Anise) J. Pl. Biochem. Biotech. 6: 1-5.

Hanida SS and Kapoor VK (1988). Pharmacognosy. Vallabh Prakashhan Educational Publishers, Delhi.

Hossain SN, Rahman S, Joydhar A, Islam S and Hossain M (2000). In vitro propagation of Thankuni (Centella asiatica L.), Plant Tissue Cult. 10(1): 17-23.

Hossain A, Hossain T, Raihan A and Rahman M (2005). Effect of different carbon sources on in vitro regeneration of Indian pennywort (Centella asiatica) Pakistan Journal of Biological Sciences. 8(7): 963-965. 
Kirtikar KR and Basu BD (1975). Indian medicinal plants. Vol. II, Joyyed Press, New Delhi.

Nath KT, Sharma, NC, Tiwari V and Brahma DS (2000). In vitro clonal propagation of Centella asiatica. Plant cell, Tissue and organ culture. 63(7): 179-185.

Nath S and Buragohain A K (2003). Plant Biochemistry and Biotechnology. 12:167-169.

'O' Neill M and Lewis A (1993). Human medicinal agents from plants. In: Kinghorn AD Balandrin MF, ACS symposium Series 534, Washington, DC. pp.48.

Prajapati ND, Purohit SS, Sharma AK and Kumar T (2006). A handbook of medicinal plants. Hindustan Press, Agrobios, India. P.129.
Prakash ES, Valli K, Sairam PS, Reddy P and Rao KR (1999). Regeneration of Plants from seed-derived callus of Hybanthus enneaspermus L. Muell. a rare enthnobotanical herb. Plant Cell Rep. 18: 873-878.

Rahman MM (2008). Encyclopedia of Flora and Fauna of Bangladesh, Angiosperm, Dicotyledones, Vl: 155-156.

Rozita O, Abdullah MA, Hasan MA and Marziah M (2004). Development of growth medium for Centella asiatica cell culture via response surface methodology. American Journal of Applied Sciences. 1(3): 215-219, ISSN 1546-9239.

Sivakumar G, Alagumanian S and Rao MV (2006). High frequency in vitro multiplication of Centella asiatica. Eng. Life Sci. 6: 597-601.

Received: 03 May 2011; Revised : 27 November 2011; Accepted: 13 June 2012. 